\title{
APLIKASI ASSESMENT KEBIJAKAN PEMERINTAH TERKAIT OPERASI OJEK ONLINE DI MASA PANDEMI (COVID-19) MENGGUNAKAN ALGORITMA NAÏVE BAYES CLASSIFIER
}

\section{Application Of Government Policy Assessment Related To Online Oject Operations In The Pandemic Time (COVID-19) Using The Nä̈ve Bayes Classifier Algorithm}

\author{
Edwin, edwin9660@yahoo.com ${ }^{1)}$ \\ ${ }^{1)}$ Customer Service Department, Bank Central Asia Citra Garden , Indonesia
}

\begin{abstract}
The pandemic (Covid-19) entered Indonesia around April 2020. Various government policies began to be established to break the chain of Covid-19 spread. Many sectors have been affected by the pandemic, ranging from government, MSMEs, traders, students or university students, including online motorcycle taxis. The online motorcycle taxi itself is a transformation from the conventional ojek located at a base to wait for customers, or so-called pangkalan ojek. Online motorcycle taxi is one of the professions that have been affected by Covid-19 and at the same time directly experienced the government's policy, where the government banned online motorcycle taxi operations during the Large-Scale Social Restrictions (PSBB) period. Government policies have a huge impact on online motorcycle taxi drivers where online motorcycle taxis are the main livelihood for drivers. Various kinds of public reactions to government policies make people think about the comparison of people's assessments of the current government in overcoming problems in the eyes of the community, especially the Pandemic (Covid-19) entered Indonesia around April 2020. Various government policies have begun to be established to break the chain of Covid-19 spread. . Many sectors have been affected by the pandemic, ranging from government, MSMEs, traders, students or university students, including online motorcycle taxis. The online motorcycle taxi itself is a transformation from the conventional ojek located at a base to wait for customers, or socalled pangkalan ojek. Online motorcycle taxi is one of the professions that have been affected by Covid19 and at the same time directly experienced the government's policy, where the government banned online motorcycle taxi operations during the Large-Scale Social Restrictions (PSBB) period. Government policies have a huge impact on online motorcycle taxi drivers where online motorcycle taxis are the main livelihood for drivers. Various kinds of public reactions to government policies make people think in comparison to people's assessments of the current government in overcoming problems in the eyes of the community, especially the operational policies of online motorcycle taxi drivers. This research will build a system that accommodates online motorcycle taxi assessments using the website-based Naive Bayes algorithm, where the system can analyze the assessment data using the Naive Bayes algorithm and produce a percentage comparison of happy or grim response categories (tweets) that will be known and used as a response analysis tool for policies. government. This study has produced a classification system for the Happy and Gloomy categories using the Nä̈ve Bayes algorithm, with an accuracy of $92 \%$ obtained using 500 data.
\end{abstract}

Keywords: Assesment Ojek Online, Naïve Bayes, Covid-19

\begin{abstract}
ABSTRAK
Pandemi (Covid-19) masuk ke Indonesia sekitar bulan april 2020. Berbagai kebijakan pemerintah mulai ditetapkan demi memutuskan rantai penyebaran Covid-19. Banyak sektor yang terkena dampak akibat pandemi, mulai dari pemerintahan, UMKM, pedagang, pelajar atau mahasiswa, tak terkecuali ojek online. Ojek online sendiri merupakan transformasi dari ojek konvensional yang bertempat di suatu pangkalan
\end{abstract}


untuk menunggu pelanggan, atau biasa disebut ojek pangkalan. Ojek online merupakan salah satu profesi yang terdampak Covid-19 dan sekaligus merasakan langsung kebijakan pemerintah yang diambil, dimana pemerintah melarang operasi ojek online selama masa Pembatasan Sosial Berskala Besar (PSBB). Kebijakan pemerintah sangat berdampak bagi driver ojek online dimana ojek online adalah mata pencaharian utama bagi driver. Berbagai macam reaksi masyarakat atas kebijakan pemerintah membuat masyarakat berfikir perbandingan penilaian masyarakat terhadap pemerintahan saat ini dalam mengatasi permasalahan dimata masyarakat, khususny Pandemi (Covid-19) masuk ke Indonesia sekitar bulan april 2020. Berbagai kebijakan pemerintah mulai ditetapkan demi memutuskan rantai penyebaran Covid-19. Banyak sektor yang terkena dampak akibat pandemi, mulai dari pemerintahan, UMKM, pedagang, pelajar atau mahasiswa, tak terkecuali ojek online. Ojek online sendiri merupakan transformasi dari ojek konvensional yang bertempat di suatu pangkalan untuk menunggu pelanggan, atau biasa disebut ojek pangkalan. Ojek online merupakan salah satu profesi yang terdampak Covid-19 dan sekaligus merasakan langsung kebijakan pemerintah yang diambil, dimana pemerintah melarang operasi ojek online selama masa Pembatasan Sosial Berskala Besar (PSBB). Kebijakan pemerintah sangat berdampak bagi driver ojek online dimana ojek online adalah mata pencaharian utama bagi driver. Berbagai macam reaksi masyarakat atas kebijakan pemerintah membuat masyarakat berfikir perbandingan penilaian masyarakat terhadap pemerintahan saat ini dalam mengatasi permasalahan dimata masyarakat, khususnya kebijakan operasional driver ojek online. Pada penelitian akan membangun sistem yang menampung assesment ojek online menggunakan algoritma Naive Bayes berbasis website, dimana sistem tersebut dapat menganalisa data assesment menggunakan algoritma Naive Bayes dan menghasilkan persentase perbandingan kategori respon (tweet) bahagia atau muram akan diketahui dan digunakan sebagai alat analisa respon terhadap kebijakan pemerintah. Penelitian ini telah menghasilkan sistem klasifikasi kategori Bahagia dan Muram menggunakan alogritma Nä̈ve Bayes, dengan akurasi 92\% didapatkan menggunakan 500 data.

Kata Kunci: Assesment Ojek Online, Naïve Bayes, Covid-19

\section{PENDAHULUAN}

Pandemi (Covid-19) masuk ke Indonesia sekitar bulan april 2020. Berbagai kebijakan pemerintah mulai ditetapkan demi memutuskan rantai penyebaran Covid-19. Banyak sektor yang terkena dampak akibat pandemi, mulai dari pemerintahan, UMKM, pedagang, pelajar atau mahasiswa, tak terkecuali ojek online. Pada 31 Maret 2020, Presiden Republik Indonesia menerbitkan Peraturan Pemerintah Pengganti UU No 1 Tahun 2020 (PERPPU 01/2020) tentang Kebijakan Keuangan Negara dan Stabilitas Sistem Keuangan untuk Penanganan Pandemi Corona Virus Disease 2019 (Covid-19) dan/atau dalam Rangka Menghadapi Ancaman yang Membahayakan Perekonomian Nasional dan/atau Stabilitas Sistem Keuangan. Total anggaran untuk ini adalah sebesar Rp 405,1 triliun. Peraturan Menteri Kesehatan No. 9 Tahun 2020 tentang Pedoman PSBB dalam rangka Percepatan Penanganan Covid-19 ditetapkan pada 3 April 2020. Kebijakan PSBB antara lain; peliburan sekolah dan tempat kerja, pembatasan kegiatan keagamaan, pembatasan kegiatan di tempat/fasilitas umum, pembatasan kegiatan sosial budaya, pembatasan moda transportasi, dan pembatasan kegiatan lainnya terkait aspek pertahanan dan keamanan.

Ojek online sendiri merupakan transformasi dari ojek konvensional yang bertempat di suatu pangkalan untuk menunggu pelanggan, atau biasa disebut ojek pangkalan. Kemudahan dalam pemesanannya dengan menggunakan teknologi smartphone membuat ojek online semakin diminati. Hal ini dapat menjadi solusi transportasi di Indonesia, terutama di kota besar yang seringkali mengalami kemacetan. Ojek yang merupakan kendaraan menggunakan sepeda motor, sangat efektif untuk mobilitas di kemacetan kota. Ojek online merupakan salah satu profesi yang terdampak Covid-19 dan sekaligus merasakan langsung kebijakan pemerintah yang diambil, dimana pemerintah melarang operasi ojek online selama masa Pembatasan Sosial Berskala Besar (PSBB). Kebijakan pemerintah terhadap pelarangan moda transportasi ojek online untuk beroperasi menimbulkan banyak reaksi masyarakat Indonesia, reaksi tersebut banyak tertuang di media sosial 
twitter. Kebijakan pemerintah sangat berdampak bagi driver ojek online dimana ojek online adalah mata pencaharian utama bagi driver. Berbagai macam reaksi masyarakat atas kebijakan pemerintah membuat masyarakat berfikir perbandingan penilaian masyarakat terhadap pemerintahan saat ini dalam mengatasi permasalahan dimata masyarakat, khususnya kebijakan operasionaldriver ojek online. Berdasarkan permasalahan tersebut maka dibutuhkan sistem yang dapat melakukan klasifikasi tweet menggunakan algoritma naive bayes.

Seperti penelitian yang dilakukan oleh, membahas tentang komentar atau tweet mengenai film yang ada pada Twitter dapat dijadikan sebagai evaluasi dalam menonton film dan meningkatkan produksi film. Untuk mengetahui hal tersebut, analisis sentimen dapat digunakan untuk mengklasifikasikan kedalam sentimen negatif, netral atau positif. Didalam Tweet terkandung banyak ragam bahasa yang digunakan, yaitu diantaranya bahasa dalam bentuk tidak baku seperti bahasa slang, penyingkatan kata, dan salah eja. Oleh sebab itu dibutuhkan penanganan khusus pada Tweet. Pada penelitian ini digunakan kamus kata tidak baku dan normalisasi Levenshtein Distance untuk memperbaiki kata yang tidak baku menjadi kata baku dengan pengklasifikasian Naive Bayes. Berdasarkan hasil pengujian yang telah dilakukan didapatkan akurasi tertinggi dengan nilai accuracy, precision, recall, dan f-measure sebesar 98.33\%, 96.77\%, 100\%, dan $98.36 \%$.

Berdasarkan permasalahan diatas maka dibuat penelitian dengan judul "Aplikasi Assesment Kebijakan Pemerintah Terkait Operasi Ojek Online Di Masa Pandemi (Covid-19) menggunakan Algoritma Nä̈ve Bayes Classifier", dimana sistem tersebut dapat menganalisa data assesment menggunakan algoritma Naive Bayes dan menghasilkan persentase perbandingan kategori respon (tweet)bahagia atau muram akan diketahui dan digunakan sebagai alat analisa respon terhadap kebijakan pemerintah

\section{METODE PENELITIAN}

Penelitian ini bertujuan untuk pengembangan dan masukan kepada kebijakan terkait covid-19 saat ini, sebagai masukan tambahan kepada instansi pemerintahan / Lembaga terkait dalam mengkaji kebijakan yang sedang berjalan

\section{Studi Pustaka}

Melakukan penelitian terhadap kepustakaan tentang algoritma probabilitas yaitu teknik Naïve Bayes Classifier. Bahanbahan studi pustaka yang digunakan diperoleh dari publikasi paper local dan internasional, jurnal local dan internasional, tesis-tesis dan sumber-sumber lain dari internet.

\section{HASIL DAN PEMBAHASAN}

\section{Pengumpulan Data}

Data yang diperoleh merupakan kumpulan data yang didapatkan dengan menggunakan web scraping pada twitter

\section{Preprocessing}

Proses yang dilakukan dalam tahapan ini adalah sebagai berikut:

a. CaseFolding, yaitu untuk menyeragamkan bentuk huruf.

b. Tokenizing, yaitu pemenggalan suku kata

c. Stopword, yaitu menghilangkan kata yang tidak deskriptif.

d. Stemming, yaitu mengubah suku kata menjadi kata dasar.

\section{Pelabelan}

Pelabelan adalah tahapan dimanas elebgram diberi label yang nantinya akan digunakan pada proses training di tahap klasifikasi. Terdapat beberapa label kategori tweet yaitu bahagia atau muram terkait kebijakan pemerintah terkait operasi ojek online di masa pandemi Covid-19. Pelabelan dilakukan dengan 
menggunakan sistem. Hasil dari tahapan ini adalah kumpulan dataset yang memiliki label.

1. Klasifikasi

Proses klasifikasi dibedakan menjadi dua proses yaitu:

a. Training, proses ini digunakan untuk melatih algoritma klasifikasi yang digunakan yaitu algoritma Nä̈ve Bayes agar mampu melakukan prosesnya sesuai dengan yang diharapkan. Pada tahap ini pertama-tama akan dilakukan proses pembobotan terhadap kumpulan datahasil pelabelan menggunakan perhitungan TF-IDF dengan hanya menghitung TF (term frequncy)-nya saja. Selanjutnya akan dihasilkan model klasifikasi yang nantinya digunakan pada tahap testing.

b. Testing, proses ini dilakukan untuk melakukan pengklasifikasian terhadap dataset dengan memanfaatkan model klasifikasi yang dihasilkan pada proses training. Hasil pada tahap ini adalah kumpulandatayang telah diklasifikasikan ke dalam kategori kebijakan pemerintah.

\section{Algoritma Naïve Bayes}

Pada tahap ini menghasilkan hasil klasifikasi dari Algoritma naive bayes adalah suatu model independen yang membahas mengenai klasifikasi sederhana berdasarkan teorema Bayes (Kurniawan, 2018). Naïve Bayes merupakan suatu algoritma yang dapat mengklasifikasikan suatu variable tertentu dengan menggunakan metode probabilitas dan statistik. Secara garis besar algoritma Naïve Bayes dapat dilihat pada persamaan (1)

$$
P(E \mid S)=\frac{P\left[R p_{p}(S \mid R]\right.}{\rho(s)}
$$

Keterangan :

$\mathrm{R}$ : Data yang belum diketahui kelasnya

$\mathrm{S}$ : Hipotesis pada data $\mathrm{R}$ yang merupakan class khusus

$\mathrm{P}(\mathrm{RIS})$ : Nilai probabilitas pada hipotesis $\mathrm{R}$ yang berdasarkan kondisi

S P(R) : Nilai probabilitas pada hipotesis
$\mathrm{R} \quad \mathrm{P}(\mathrm{S} \mid \mathrm{R})$ : Nilai probabilitas $\mathrm{S}$ yang berdasarkan dengan kondisi hipotesis

R P(S) : Nilai probabilitas $S$

Dengan menggunakan persamaan diatas, data yang telah diperoleh dapat diproses dengan algoritma Naive Bayes untuk penilaian data yang akan diklasifikasikan.

\section{Evaluasi Alogritma}

Metode evaluasi model klasifikasi yang digunakan pada penelitian ini adalah Holdout dimana sebanyak setengah atau dua per tiga dari data keseluruhan untuk keperluan proses training sedangkan sisanya digunakan untuk keperluan testing [8].

Metode lain yang digunakan untuk evaluasi adalah confusion matrix. Confusion matrix merupakan salah satu tools penting dalam metode visualisasi yang digunakan pada mesin pembelajaran yang biasanya memuat dua kategori atau lebih. Tabel 1 menjelaskan contoh hasil confusion matrix prediksi kedua kelas

Tabel 1 Hasil Confusion Matrix

\begin{tabular}{|c|c|c|c|}
\hline \multicolumn{2}{|c|}{} & \multicolumn{2}{|c|}{ Nilai Aktal } \\
\cline { 3 - 4 } Nilai & Positive & Positive & Negative \\
Aktu & & True Positive & False Positive \\
al & Negative & False Negative & (FP) \\
\cline { 3 - 4 } & & True \\
& & (FN) & Negative(TN) \\
\hline
\end{tabular}

\section{METODE PENELITIAN}

Desain arsitektur sistem dapat dilihat pada Gambar 1. Terdiri dari 7 blok proses yaitu Pengumpulan Data, PReprocessing, Pelabelan, Training dan pembobotan klasifikasi Naïve Bayes, Model Klasifikasi, Testing Klasifikasi Naïve Bayes, Hasil klasfikasi.

Sedangkan Use case dapat dilihat pada gabmar 2, terdiri dari seorang Aktor 
Admin, dan Use case-use case yang terdri dari kelola user, tambah data training, KEloloa Data training, Kelola KAtegori, dan testing Data serta sebuah use case login

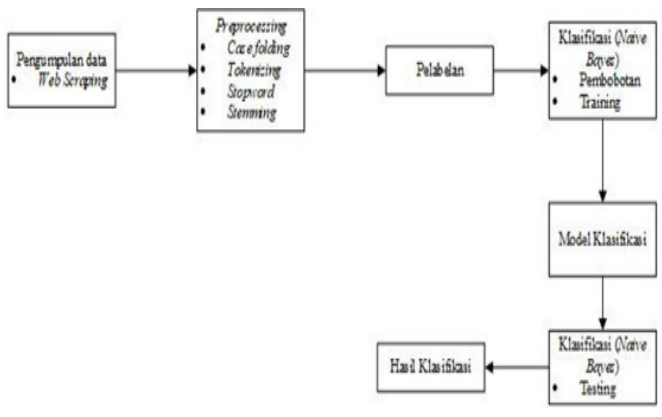

Gambar 1 Desain Sistem

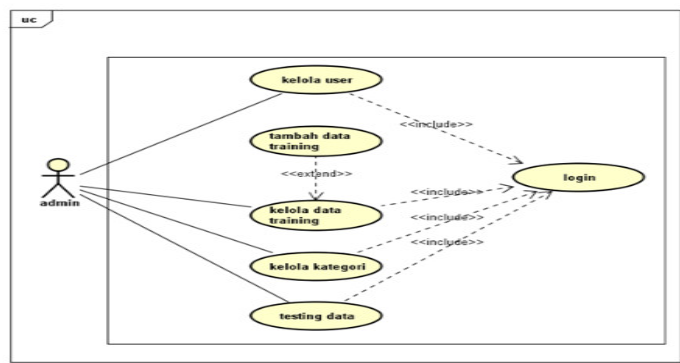

Gambar 2 Use Case Diagram

1) Halaman Scrapping Logs

Pada halaman scraping ini terdapat proses scraping dengan mengambil nilai dari twitter dengan keyword, query type, since,until, dan max tweet. Gambar 3 menunjukkan bentuk hasil impelementasi halaman scraping logs.

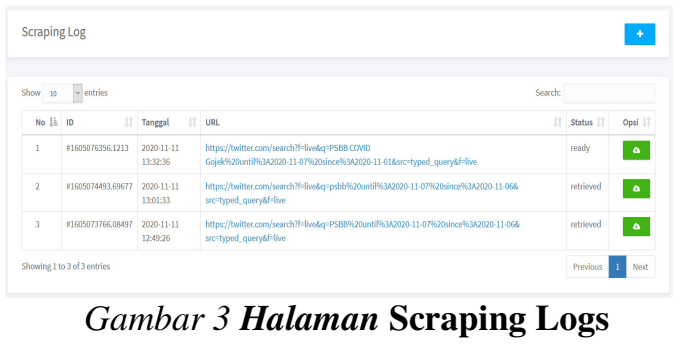

2) Halaman Training Data

Pada halaman ini terdapat proses mengelola data training dengan mengambil nilai dari database. Dan user dapat melihat semua daftar training yang ada dan berfungsi untuk mengelola data training. Pada data training terdapat preprocessing seperti variable casefolding, tokenizing, stopward, dan stemming. Gambar 4 merupakan bentuk hasil impelementasi halaman data training.

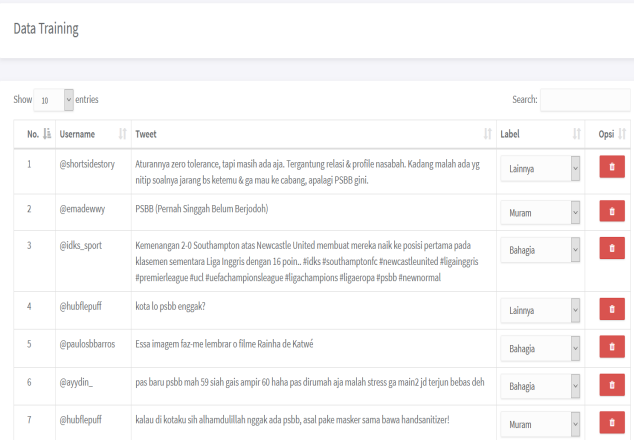

Gambar 4 Halaman Data Training

3) Halaman Confusion Matrix

Pada proses perhitungan confusion matrix berdasarkan label hasil klasifikasi menggunakan naïve bayes. Gambar 5 memperagakan bentuk hasil impelementasi halaman confusion matrix.

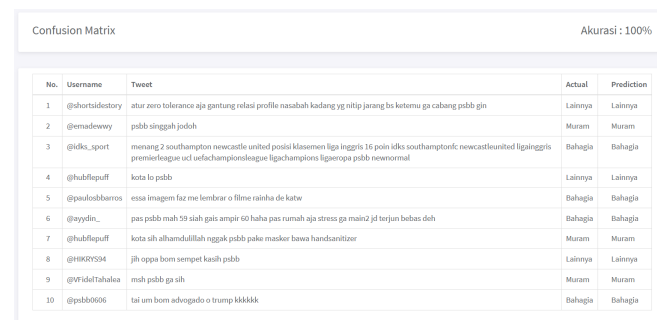

Gambar 5 Halaman Confusion Matrix

Tahap Pengujian Metode Nä̈ve Bayes merupakan tahap penentuan keterhubungan antara kata-kata pada data. Tahap ini menggunakan sebuah algoritma Naive Bayes Classifier. Naive Bayes Classifier terdiri dari dua proses dalam proses klasifikasi datanya. Kedua proses itu adalah proses pembelajaran Naive Bayes Classifier dan proses klasifikasi Naive Bayes Classifier. Dataset ditunjukkan pada Tabel 2. 
Tabel 2 Dataset

\begin{tabular}{|l|l|}
\hline D1 & $\begin{array}{l}\text { munculin kebijakan ditengah } \\
\text { pandemi yang merusak hati kami } \\
\text { para ojol. }\end{array}$ \\
\hline D2 & $\begin{array}{l}\text { dimasa seperti ini justru sangat } \\
\text { mengecewakan \#pemerintah }\end{array}$ \\
\hline D3 & $\begin{array}{l}\text { Kita ambil hikmahnya, mungkin ini } \\
\text { yang terbaik. }\end{array}$ \\
\hline D4 & $\begin{array}{l}\text { Rakyat dan pemerintah harus } \\
\text { kompak }\end{array}$ \\
\hline D5 & semoga indonesia baik-baik saja. \\
\hline
\end{tabular}

Tabel 3 TF-IDF

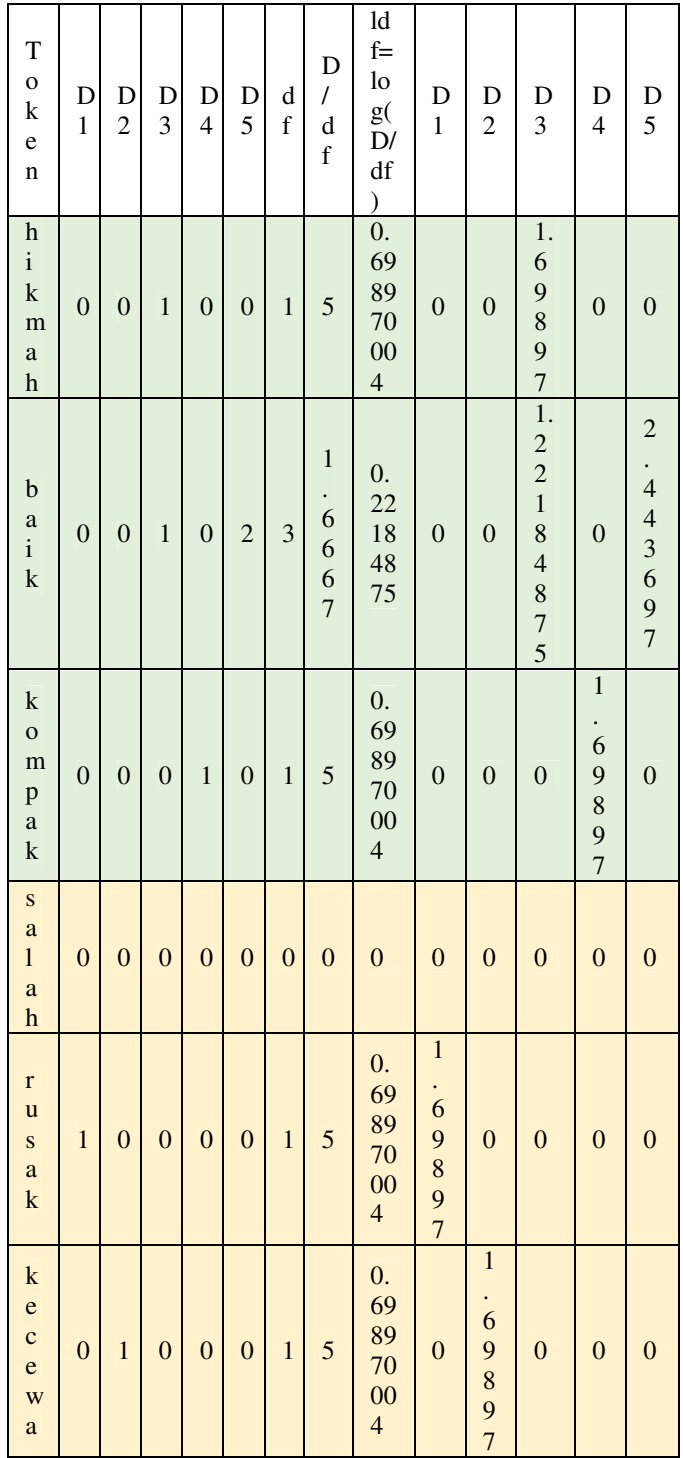

Dalam klasifikasi analisis, pembobotan kata digunakan untuk mendapatkan suatu kategori. Salah satu metode pembobotan adalah TF-IDF (Term Frequency -Inverse Document Frequency).

Nilai bobot suatu kata (term) menyatakan kepentingan bobot tersebut dalam merepresentasikan judul. Pada pembobotan Tabel 3, TF-IDF, bobot akan semakin besar jika frekuensi kemunculan kata semakin tinggi, tetapi bobot akan berkurang jika kata tersebut semakin sering muncul pada analisis.

Tahap ini melakukan perhitungan pada kata yang terdapat data test dan menggunakan tabel 4 Klasifikasi:

\section{Tabel 4 Klasifikasi}

\begin{tabular}{|l|l|l|}
\hline & Bahagia & Muram \\
\hline$p$ (Klasifikasi) & 7.063486 & 3.39794 \\
\hline$p$ (persentase) & 0.675193 & 0.324807 \\
\hline
\end{tabular}

$P\left(a_{i} \mid V_{j}\right)=\frac{n_{k}+1}{n+\mid \text { kata } \mid}$

Perhitungan $\mathrm{P}\left(\mathrm{a}_{\mathrm{i}} \mid \mathrm{V}_{\mathrm{j}}\right)$ sebagai berikut:

$\mathrm{P}($ "makan" । bahagia) = $\frac{0+1}{7.063486+2}-0.110333$

Matching : mencari tern yang sama pada data training dan testing. PErhitungan pada mataching diperagakan pada Tabel 5 .

Tabel 5 Perhitungan pada Matching

\begin{tabular}{|l|l|l|l|l|l|l|l|}
\hline & $\begin{array}{l}\text { hik } \\
\text { ma } \\
\text { h }\end{array}$ & baik & $\begin{array}{l}\text { ko } \\
\text { mp } \\
\text { ak }\end{array}$ & salah & $\begin{array}{l}\text { rus } \\
\text { ak }\end{array}$ & $\begin{array}{l}\text { kec } \\
\text { ewa }\end{array}$ & nilai \\
\hline D6 & 0 & 0 & 0 & 0 & 1 & 1 & \\
\hline Ba & 0.1 & 0.110 & 0.1 & 0.110 & 0.2 & 0.2 & 0.882 \\
ha & 103 & 3328 & 103 & 3328 & 206 & 206 & 6625 \\
gia & 33 & 2 & 33 & 2 & 66 & 66 & 62 \\
\hline Mu & 0.1 & 0.185 & 0.1 & 0.185 & 0.3 & 0.3 & 1.482 \\
ra & 852 & 2558 & 852 & 2558 & 705 & 705 & 0468 \\
m & 56 & 57 & 56 & 57 & 12 & 12 & 53 \\
\hline
\end{tabular}

Kemudian dengan menggunakan rumus dan mencari nilai maksimum untuk menentukan hasil klasifikasi menghasilkan 
Perhitungan pada Laplace Smoothing seperti yang ditunjukkan pada Tabel 6

Tabel 6 Perhitungan pada Laplace Smoothing

\begin{tabular}{|c|c|c|c|c|c|c|c|c|}
\hline & $\begin{array}{l}\mathrm{Hi} \\
\mathrm{km} \\
\mathrm{ah}\end{array}$ & baik & $\begin{array}{l}\text { ko } \\
\text { mp } \\
\text { ak }\end{array}$ & $\begin{array}{l}\text { sala } \\
\mathrm{h}\end{array}$ & $\begin{array}{l}\mathrm{Ru} \\
\mathrm{sa} \\
\mathrm{k}\end{array}$ & $\begin{array}{l}\text { ke } \\
\text { ce } \\
\text { wa }\end{array}$ & nilai & \\
\hline $\begin{array}{l}\mathrm{D} \\
6 \\
\end{array}$ & 0 & 0 & 0 & 0 & 1 & 1 & & \\
\hline $\begin{array}{l}\mathrm{Ba} \\
\text { ha } \\
\text { gi } \\
\text { a }\end{array}$ & $\begin{array}{l}0.1 \\
10 \\
33 \\
3\end{array}$ & $\begin{array}{l}0.11 \\
033 \\
282\end{array}$ & $\begin{array}{l}0.1 \\
10 \\
33 \\
3\end{array}$ & $\begin{array}{l}0.11 \\
033 \\
282\end{array}$ & $\begin{array}{l}0.2 \\
20 \\
66 \\
6\end{array}$ & $\begin{array}{l}0.2 \\
20 \\
66 \\
6\end{array}$ & $\begin{array}{l}0.88 \\
266 \\
256 \\
2\end{array}$ & $\begin{array}{l}6.36 \\
917 \\
\text { E- } \\
06\end{array}$ \\
\hline $\begin{array}{l}\text { M } \\
\text { ur } \\
\mathrm{a} \\
\mathrm{m}\end{array}$ & $\begin{array}{l}0.1 \\
85 \\
25 \\
6\end{array}$ & $\begin{array}{l}0.18 \\
525 \\
585 \\
7\end{array}$ & $\begin{array}{l}0.1 \\
85 \\
25 \\
6\end{array}$ & $\begin{array}{l}0.18 \\
525 \\
585 \\
7\end{array}$ & $\begin{array}{l}0.3 \\
70 \\
51 \\
2\end{array}$ & $\begin{array}{l}0.3 \\
70 \\
51 \\
2\end{array}$ & $\begin{array}{l}1.48 \\
204 \\
685 \\
3\end{array}$ & $\begin{array}{l}0.00 \\
023 \\
963 \\
7\end{array}$ \\
\hline \multicolumn{8}{|c|}{ Nilai Maksimal } & $\begin{array}{l}0.00 \\
023 \\
963 \\
7\end{array}$ \\
\hline
\end{tabular}

Dari hasil perhitungan probabilitas diketahui bahwa dokumen 6 (D6) memiliki nilai yang paling tinggi, sehingga testing masuk kedalam dokumen 6 atau kategori muram.

\section{Evaluasi Performasi}

Tabel 7 Data Pelattihan dan Data Pengujian

\begin{tabular}{|l|l|l|l|}
\hline \multicolumn{2}{|l|}{ Perbandingan Data } & \multicolumn{2}{l|}{ Jumlah Data } \\
\hline $\begin{array}{l}\text { Data } \\
\text { Pelatihan }\end{array}$ & $\begin{array}{l}\text { Data } \\
\text { Pengujian }\end{array}$ & $\begin{array}{l}\text { Data } \\
\text { Pelatihan }\end{array}$ & $\begin{array}{l}\text { Data } \\
\text { Pengujian }\end{array}$ \\
\hline $80 \%$ & $20 \%$ & 400 & 100 \\
\hline
\end{tabular}

Pada table 7 dijelaskan hasil dari akuisi data kemudian lewat preprocessing data yang ada sebanyak 100 yang dibagi dalam 2 sentiment yaitu kategoril adalah Bahagia dan kategori2 adalah Muram. Data yang sudah dinormalisasi sebelum dimasukkan kemesin klasifikasi, data tersebu dibagi menjadi dua yaitu data pelatihan dan data pengujian dengan menggunakan confusion matrix.

\section{Tabel 8 Hasil Tes}

\begin{tabular}{|c|c|c|}
\hline \multirow{2}{*}{ Actual class } & \multicolumn{2}{|c|}{ Predicted class } \\
\cline { 2 - 3 } & Kategori 1 & Kategori 2 \\
\hline Kategori 1 & 45 & 5 \\
\hline Kategori 2 & 3 & 47 \\
\hline
\end{tabular}

Kategori 1:

$$
\begin{aligned}
& \text { Precision }=\frac{45}{(45+3)}=0.93 \\
& \text { Recall }=\frac{45}{(45+5)}=0.9 \\
& F-\text { Measure }=\frac{2 * \text { recall } * \text { prectston }}{\text { recall }+ \text { pretston }}=\frac{2 * 0.9 * 0.93}{0.9+0.93}=0.91
\end{aligned}
$$

Kategori 2:

$$
\begin{aligned}
& \text { Precision }=\frac{47}{(47+5)}=0.90 \\
& \text { Recall }=\frac{47}{(3+47)}=0.94 \\
& F-\text { Measure }=\frac{2 * \text { recall } * \text { precision }}{\text { recall }+ \text { prectston }}=\frac{2 * 0.94 * 0.90}{0.94+0.90}=0.91
\end{aligned}
$$

Accuracy:

$$
\text { Accuracy }=\frac{(45+47)}{(45+5+47+3)} * 100 \%=92 \%
$$

\section{KESIMPULAN}

Berdasarkan hasil implementasi dan uji coba yang telah dilakukan, maka dapat disimpulkan hasil penelitian ini adalah sebagai berikut :

1. Sistem analisa sentiment kebijakan pemerintah terkait operasi ojek online di masa pandemi covid-19 yang dilakukan dengan menggunakan algoritma Nä̈ve Bayes menggunakan data yang diambil menggunakan webscraping pada twitter yang diproses dengan text mining yaitu proses casefolding, tokenizing, stopword dan stemming. Setelah didapat kata kunci dari proses text mining akan dilakukan perhitungan dengan Naïve Bayes yang menghasilkan keluaran berupa kategori Bahagia dan Muram.

2. Penelitian ini telah menghasilkan sistem klasifikasi kategori Bahagia dan Muram.

3. Hasil pengujian algoritma Nä̈ve Bayes dipengaruhi oleh kapasitas data yang digunakan dimana akurasi 92\% didapatkan menggunakan 500 data.

\section{DAFTAR PUSTAKA}


[1] Antinasari, P., Perdana, R. S., \& Fauzi, M. A. (2017). Analisis Sentimen Tentang Opini Film Pada Dokumen Twitter Berbahasa Indonesia Menggunakan Naive Bayes Dengan Perbaikan Kata Tidak Baku. Retrieved from https://www.researchgate.net/profil e/Rizal_Perdana/publication/32023 4777_Analisis_Sentimen_Tentang Opini_Film_pada_Dokumen_Twitt er_Berbahasa_Indonesia_Menggun akan_Naive_Bayes_dengan_Perbai kan_Kata_Tidak_Baku/links/59d65 1faa6fdcc52aca7c744/AnalisisSentime

[2] Antinasari, P., Perdana, R. S., \& Fauzi, M. A. (2017). Analisis Sentimen Tentang Opini Film Pada Dokumen Twitter Berbahasa Indonesia Menggunakan Naive Bayes Dengan Perbaikan Kata Tidak Baku. Retrieved from https://www.researchgate.net/profil e/Rizal_Perdana/publication/32023 4777_Analisis_Sentimen_Tentang_ Opini_Film_pada_Dokumen_Twitt er_Berbahasa_Indonesia_Menggun akan_Naive_Bayes_dengan_Perbai kan_Kata_Tidak_Baku/links/59d65 1 faa6fdcc52aca7c744/AnalisisSentime

[3] Claudy, Y. I., Perdana, R. S., \& Fauzi, M. A. (2018). Klasifikasi Dokumen Twitter Untuk Mengetahui Karakter Calon Karyawan Menggunakan Algoritme K-Nearest Neighbor (KNN). Retrieved from https://www.researchgate.net/profil e/Muhammad_Fauzi30/publication/ 322959490_Klasifikasi_Dokumen_ Twitter_Untuk_Mengetahui_Karakt er_Calon_Karyawan_Menggunaka n_Algoritme_K-

Nearest_Neighbor_KNN/links/5a79 c31aa6fdcc4ffe927325/KlasifikasiDokumen-Twitter-Untuk-

[4] Hendini, A. (2016). Pemodelan UML Sistem Informasi Monitoring
Penjualan dan Stok Barang (Studi Kasus: Distro Zhezha Pontianak). Jurnal Khatulistiwa Informatika, Vol. 4, No.2. ISSN 2339-1928.

[5] Hidayatullah, A. F., \& SN, A. (2014). ANALISIS SENTIMEN DAN KLASIFIKASI KATEGORI TERHADAP TOKOH PUBLIK PADA TWITTER. Retrieved from http://www.jurnal.upnyk.ac.id/inde x.php/semnasif/article/download/10 $16 / 977$

[6] Kurniawan, Y. I. (2018). PERBANDINGAN ALGORITMA NAIVE BAYES DAN C.45 DALAM KLASIFIKASI DATA MINING. Retrieved from http://digilib.mercubuana.ac.id/man ager/t!@file_artikel_abstrak/Isi_Art ikel_188474085926.pdf

[7] Ling, J., N. Kencana, I. E., \& Oka, T. B. (2014). ANALISIS SENTIMEN MENGGUNAKAN METODE NAÏVE BAYES CLASSIFIER DENGAN SELEKSI FITUR CHI SQUARE. Retrieved from https://www.researchgate.net/profil e/I_Putu_Eka_N_Kencana2/publica tion/319082374_ANALISIS_SENT IMEN_MENGGUNAKAN_METO DE_NAIVE_BAYES_CLASSIFIE R_DENGAN_SELEKSI_FITUR_C HI_SQUARE/links/599233feaca27 289539bba83/ANALISIS-

SENTIMEN-MENGGUNAKANMETODE-NAIVE-BAYES-CL

[8] Mulyani, A. (2018). Analisis Penerimaan dan Penggunaan Teknologi Aplikasi Ojek Online Menggunakan Unified Theory of Acceptance and Use Technology. Retrieved from https://sttgarut.ac.id/jurnal/index.ph p/algoritma/article/view/479

[9] Nugroho, D. G., Chrisnanto, Y. H., \& Wahana, A. (2016). ANALISIS SENTIMEN PADA JASA OJEK ONLINE MENGGUNAKAN 
$\begin{array}{lrr}\text { METODE } & \text { NAÏVE } & \text { BAYES. } \\ \text { Retrieved } & \text { from }\end{array}$ https://www.publikasiilmiah.unwah as.ac.id/index.php/PROSIDING_S NST_FT/article/view/1526/1609

[10] Nugroho, D. G., Chrisnanto, Y. H., \& Wahana, A. (2016). ANALISIS SENTIMEN PADA JASA OJEK ONLINE MENGGUNAKAN METODE NAÏVE BAYES. Retrieved from https://www.publikasiilmiah.unwah as.ac.id/index.php/PROSIDING_S NST_FT/article/view/1526/1609

[11] Nurjanah, W. E., Perdana, R. S., \& Fauzi, M. A. (2017). Analisis Sentimen Terhadap Tayangan Televisi Berdasarkan Opini Masyarakat pada Media Sosial Twitter menggunakan Metode KNearest Neighbor dan Pembobotan Jumlah Retweet. Retrieved from https://www.researchgate.net/profil e/Rizal_Perdana/publication/32023 4745_Analisis_Sentimen_Terhadap _Tayangan_Televisi_Berdasarkan_ Opini_Masyarakat_pada_Media_So sial_Twitter_menggunakan_Metod e_K-

Nearest_Neighbor_dan_Pembobota n_Jumlah_Retweet/links/59d64d47

[12] Priadana, A., \& Murdiyanto, A. W. (2020). Pemantauan Tren Hashtag pada Instagram Menggunakan Web Scraping Instagram Hashtag Trend Monitoring Using Web Scraping. Retrieved from https://www.researchgate.net/profil e/Adri_Priadana/publication/34132 3176_Instagram_Hashtag_Trend_ Monitoring_Using_Web_Scraping/1
inks/5ebac3d392851c11a8618e8e/I nstagram-Hashtag-TrendMonitoring-Using-WebScraping.pdf

[13] Setiawan, A. R. (2020). Lembar Kegiatan Siswa untuk Pembelajaran Jarak Jauh Berdasarkan Literasi Saintifik pada Topik Penyakit Coronavirus 2019 (COVID-19). Retrieved from https://thesiscommons.org/7tngk/

[14] Simatupang, A. R. (2020). Analisis Proses Pada Senayan Library Information Management System (SLIMS) Cendana Berbasis Data Flow Diagram (DFD) Di Perpustakaan Universitas Kristen Duta Wicana Yogyakarta. Retrieved from http://jurnal.uinsu.ac.id/index.php/ji pi/article/view/7217

[15] Sovia, R., \& Febio , J. (2017). MEMBANGUN APLIKASI ELIBRARY MENGGUNAKAN HTML, PHP SCRIPT, DAN MYSQL DATABASE. Retrieved from http://ejournal.stikomdb.ac.id/index.php/processor/article /download/28/27

[16] Trisna Lestari, A. R., Perdana, R. S., \& Fauzi, M. A. (2017). Analisis Sentimen Tentang Opini Pilkada DKI 2017 Pada Dokumen Twitter Berbahasa Indonesia Menggunakan Naïve Bayes dan Pembobotan Emoji. Retrieved from http://jptiik.ub.ac.id/index.php/jptiik/article/view/627 